\title{
THE DEFENDANT'S CHALLENGE TO A RACIAL CRITERION IN JURY SELECTION: A STUDY IN STANDING, DUE PROCESS AND EQUAL PROTECTION
}

Collins, a Negro, was indicted, convicted and sentenced to death for the aggravated rape and attempted murder of a white woman. At the time of Collins' arrest there were no Negroes on the grand jury then sitting. ${ }^{1}$ Collins' case was not presented to this grand jury, but instead he was held in jail for six months until he could be indicted by a new grand jury. 2 This grand jury of twelve was drawn by first picking a list of twenty names, six of whom were Negroes intentionally selected because of their race in order to be "fair" to Collins. ${ }^{3}$ The twelve grand jurors then drawn by lot from the list of twenty included seven whites and five Negroes.

Collins' ultimate conviction was affirmed by the Supreme Court of Louisiana, and a petition for habeas corpus was denied by the United States District Court." On appeal, the Court of Appeals for the Fifth Circuit reversed, ${ }^{\circ}$ holding that Collins had been denied equal protection of the laws. The Fifth Circuit apparently relied on two theories in concluding that Collins' conviction was void. First, a Negro defendant "stands equal before the law, . . . is viewed by the law as a person, not as a Negro," and is denied equal protection when the grand jury is selected with regard to his race. ${ }^{7}$ Second, regardless of whether the jury was selected with reference to the defendant's race, "an accused is entitled to have charges against him considered by a jury in the selection of which there has been neither inclusion nor exclusion because of race."8

Although the constitutional grounds for decision in Collins \%. Walker may have been correct, the Fifth Circuit's opinion is inadequate because the court failed to articulate any reasons to support the constitutional theories applied in the case. The fundamental question in Collins is why the proper remedy was reversal of the conviction. If the selection of the grand jury had, in any way, affected the outcome of the case - the reliability of the determination of guilt

1. This appears to have been the result of an oversight. The jury commissioners had been instructed by the court clerk to include Negroes on the grand juries, and previous juries seemed to have had Negro representation, but in selecting the grand jury empaneled at the time of Collins' arrest each jury commissioner assumed that the other was selecting Negroes, and took no action himself. Collins v. Walker, 329 F.2d 100, 103 (5th Cir. 1964), second petition for rehearing denied, 335 F.2d 417 (5th Cir. 1964), cert. denied, 379 U.S. 901 (1964).

2. State v. Collins, 242 La. 707, 717, 138 So. $2 d$ 546, 551 (1962).

3. "I put two white man (sic) and one Negro which I figured was fair to this man." Testimony of one of the jury commissioners, 329 F.2d at 104 n.1.

4. State v. Collins, 242 La. 704, 188 So. 2d 546, cert. denied, 371 U.S. 843 (1962).

5. Collins v. Walker, 215 F. Supp. 805 (E.D. La. 1963).

6. 329 F.2d 100 (5th Cir. 1964), second petition for reliearing denied, 335 F.2d 417 (5th Cir. 1964), cert. denied, 379 U.S. 901 (1964).

7. $329 \mathrm{~F} .2 \mathrm{~d}$ at 105 .

8. 335 F.2d at 419 (on second petition for rehearing), quoting Cassel v. Texas, 339 U.S. 282, 287 (1950). 
- then the issue of remedy would appear easily disposed of on traditional due process grounds. But the Fifth Circuit never asserted that the outcome had been affected. Absent such a statement two substantive constitutional issties are raised: whether selection of the grand jury with reference to the accused's race, or solely with reference to the juror's race, constitute denials of equal protection despite the fact that the jury was so selected with a benevolent purpose. Assuming selection with regard to Collins' race was a denial of equal protection, why was reversal the proper remedy? Even more difficult questions arise in cases where selection only with reference to the jurors' race occurs and is found to be a denial of equal protection to the affected juror: does the defendant have standing to assert this denial and if so, what would be the proper remedy?

Due process clearly guarantees to all defendants the right to impartial grand and petit juries. ${ }^{9}$ If deliberate exclusion or inclusion of Negroes, or members of any other race, in the selection of a grand or petit jury affects the outcome of the case, the selection would deny the defendant an impartial tribunal, and this denial would compel reversal of the conviction. The only problem in applying this analysis to Collins, or to similar jury selection cases, lies in determining whether the method for choosing the jury destroyed the reliability of the verdict. The traditional doctrine concerning racial exclusion is embodied in the "same-class" rule:

[I]f the defendant is a member of the race or other class excluded the danger of prejudice is great enough so that we will condemn the exclusion without looking for actual prejudice; but if he is not a member of the excluded race or class the danger is not great, and before we will condemn the exclusion as unconstitutional we must find that the defendant was actually prejudiced. ${ }^{10}$

The difficulty with the "same-class rule," as applied to defendants who are not of the same race as the excluded jurors, is that despite the possibility of prejudice, the difficulty a defendant has in proving actual injury because of partiality may render the right to an impartial tribunal meaningless. It is vir-

9. This is not to say that a grand or petit jury must be used, but that whatever tribunal is used in the defendant's criminal process must be impartial. See, e.g., Tumey v. Ohio, 273 U.S. 510 (1927) ; Moore v. Dempsey, 261 U.S. 86, 91 (1923) ; Frank v. Mangum, 237 U.S. 309, 335 (1915); Jordan v. Massachusetts, 225 U.S. 167, 176 (1912).

10. Scott, The Supreme Court's Control over State and Federal Criminal Juries, 34 Iowa L. REv. 577, 584 (1949). The following are some examples of the "same-class" rule: a white man cannot complain because Negroes have been excluded: Grifin v. State, 183 Ga. 775, 190 S.E.2d (1937); Commonwealth v. Wright, $79 \mathrm{Ky} .22$ (1880); Alexander v. State, 160 Tex. Crim. 460, 274 S.W.2d 81, cert. denied, 348 U.S. 872 (1954); State v. Lea, 228 La. 724, 84 So. 2d 169 (1955); State v. Dierlamm, 189 La. 544, 180 So. 135 (1938); State v. Koritz, 227 N.C. 552, 43 S.E.2d 77, cert. devied, 332 U.S. 768 (1947); Barry v. State, 305 S.W.2d 580 (Tex. Crim.), cert. denied, 355 U.S. 851 (1957); But scc Allen v. State, 110 Ga. App. 56, 137 S.E.2d 711 (1964)، A Negro cannot complain because whites have been excluded: Haraway v. State, 203 Ark. 912, 159 S.W.2d 733 (1942). A man cannot complain because women have been excluded from his jury: State v. Jones, 44 Del. 372, 57 A.2d 109 (1947) ; State v. Taylor, 356 Mo. 1216, 205 S.W.2d 734 (1947); Winfield v. State, 293 S.W.2d 765 (Tex. Crim. 1955). 
tually impossible to use statistical data to prove prejudice. In order to do so, a defendant would have to convince the court that he was tried or indicted by a jury which was more prone to indict or convict him than other defendants. Indeed, the Supreme Court has stated that statistics are not meaningful in such cases because the existence of prejudice depends on the peculiar circumstances of each case. "II Courts thus must scrutinize each individual case for the existence of possible prejudice. But courts are equally reluctant to engage in this type of analysis ${ }^{12}$ since proof of actual prejudice would usually involve difficult and sophisticated sociological and psychological inquiry. ${ }^{13}$

Herein lies the real difficulty with the same-class rule: the opportunity for undetectable unfairness is always present when identifiable groups are arbitrarily excluded from or included in juries. ${ }^{14}$ The psychological and sociological premises underlying the same-class rule are too tenuous and too subject to the possibility of frequent exception, especially because this type of case usually involves minority groups. The reaction of minority group members, particularly members of persecuted groups, to their status may take many forms. A common reaction pattern is "self hate." An individual exhibiting this pattern is characterized by feelings of aggression toward his own group, caused by identification with the values of a dominant group. ${ }^{15}$ Similarly, class distinctions within

11. Fay v. New York, 332 U.S. 261, 280-81 (1947) ("blue-ribbon jury" challenged by attempting to show a statistical disparity in the ratio of convictions between the two jury systems). Cf. United States v. Harpole, 263 F2d 71, 79 (5th Cir.), cerl. denied, 361 U.S. 850 (1959) (suggesting that all-white juries may be prone to acquit Negroes who have committed crimes against other Negroes); Dollard, CAste ard Class ni a SoutigERN Towa 279-80 (3d ed. 1957).

12. E.g., in Alexander v. State, 160 Tex. Crim. 460, 274 S.W.2d 81, cerl. denied, 348 U.S. 872 (1954), the defendant was a white engaged in organizing both whites and Negroes in an unsegregated labor union in a segregated community. In rejecting his argument that Negroes had been excluded from jury service, and hence that he had been denied due process and equal protection, the Court tersely repeated the "same class rulc": "Not being a member of that race, appellant could not urge discrimination against members of the Negro race." Id. at 476, 274 S.W.2d at 86. See Brief of Petitioner for a Writ of Certiorari, Alexander v. State, stpra; but see Allen v. State, 110 Ga. App. 56, 137 S.E.2d 711 (1964).

13. See Fay v. New York, 332 U.S. 261, 300 (1947) (dissenting opinion); notes 15-17 infra; see also Brief for Appellant, Rabinowitz v. United States, Dkt. No. 21256 (5th Cir., June 15, 1964), pp. 30-34.

14. Of course, those who sit on a jury inevitably will make decisions that reflect their personal biases or dispositions; within the system that cannot be avoided. But any prejudice due to arbitrary or class selection is avoidable and thus intolerable.

15. Even the American Negroes share in this community of valuations: . . . under closer study, they usually reveal also that they hold something of the majority prejudice against their own kind and its characteristics.

Myrdar, An American Dilenarara xiviii (1944).

Because he has taken over American culture, the arerage Negro has also taken over something of the white American's attitude toward the Negro .... It may also be that some of the hostility felt toward the whites is deflected from them to the Negro group.

Id. at 1143. See Allport, The Nature of Prejunice 148 (Doubleday Anchor ed. 1958) (see generally ch. 9 wherein Allport details this reaction pattern to discrimination char- 
groups, resulting from attempts by members of a subgroup to disclaim the handicap which the group as a whole suffers, are apt to be quite sharp. Class distinctions among Negroes are an example - the upper-class Negro often placing the blame for his minority status upon the lower class Negro.10 Moreover, since jurors are often picked from tax lists or voting lists, the Negroes picked for jury duty are apt to be of a higher social class than the defendant, and a perfect setting is created for the operation of prejudice resulting from the strong class distinctions within minority groups. These possibilities suggest that the deliberate inclusion of Negroes on a jury, as in Collins, may well be prejudicial. ${ }^{17}$ It seems naive to say, as did the dissent in Collins, that ". . . one of the 6 [Negroes intentionally selected for Collins' jury] held a Ph.D. clegree and ... the other five were successful businessmen or farmers - independent, reasonably educated men. They were not mere 'Uncle Toms,' who had any economic or physical compulsion against them, regardless of their actions as grand jurors."18 Race is not only a criterion independently obnoxious to the law - as are also religion ${ }^{19}$ and political affiliation ${ }^{20}$ - it is also inseparably tied up with a substantial tradition of partiality. And it is because of this likelihood of prejudice that the use of racial or other arbitrary criteria in the selection of juries should lead to reversal on the ground of denial of an impartial tribunal. 21

The problem raised by Betts v. Brady ${ }^{22}$ and the solution adopted in Gidcon v. Wainwright ${ }^{23}$ present a striking analogy to the isste raised by the sameacterized by self-hate and in-group aggression); see also DoLLARD, CASTE AND CLASS IN a Southern Town ch. XIV (3d ed. 1957); Antonorsky, Identity, Auticty, and the Jezu, in Identrty and ANxIEty 431-34 (Stein, Vidich \& White, eds. 1960) (reaction of American Jews to the Rosenberg espionage case).

16. ALLPORT, op. cit. supra note 15, at 149.

17. Another, related problem would exist if a member of a group were tried or indicted for a crime which violated the group norm. For example, a Mormon who was to be tried or indicted for a crime involving drunken driving probably would not want Mormons on the jury. See Broom \& Serznick, Sociology 59-60 (3d ed. 1961).

18. 335 F.2d at 422.

19. Juarez v. State, 102 Tex. Crim 297, 277 S.W. 1091 (1925) (exclusion of Roman Catholics).

20. State v. McCarthy, 76 N.J.L. 295, 69 Atl. 1075 (Sup. Ct. 1908) (exclusion of jurors on ground of political affiliation).

21. Of course the exclusion of certain occupational classes from jury service is quite common and may be reasonable for the good of the community - for example, the common exemption of doctors, policemen, firemen. See Rawlins v. Georgia, 201 U.S. 638, 640 (1906). Members of the armed services, firemen, policemen, and public officers are exempt from service in the federal courts. 28 U.S.C. $\S 1862$ (1958). Competing policy interests can result in the exclusion of certain classes, as for example, the exemption from jury service granted to day-laborers because of financial hardship may tend to exclude Negroes. United States v. Sigler, 234 F. Supp. 171 (E.D. La. 1964). And, of coursc, reasonable standards of competency tend to under-represent certain classes. Fay v. New York, 332 U.S. 261 (1947), and discussion infra at note 29. Without more evidence, the "exclusion" in such examples cannot be said to be arbitrary or suspect.

22. 316 U.S. 455 (1942).

23. 372 U.S. 335 (1963). 
class rule Betts held that whether the conviction of a defendant without assistance of counsel denied due process depended on whether, from an examination of the "totality of facts" in a given case, there was "fundamental unfairness." What these special circumstances were was never very clear, ${ }^{20}$ but the root of the problem was that it was a heavy burden to require a showing of "fundamental unfairness" in an area in which the opportunity for undetectable unfairness is so great. Hence, asking whether the defendant was prejudiced was to ask the wrong question - a question difficult, if not impossible, to answer. ${ }^{20}$ The fact that the absence of counsel presented the opportunity for injury or unfaimess should have been the crucial point. ${ }^{27}$ Similarly, under the same class rule prejudice is presumed when Negroes are excluded from a jury which tries or indicts a Negro defendant, but in other cases, unless the defendant is a member of the excluded class, he must prove prejudice. ${ }^{23}$ Since undetectable prejudice will so often be present when there is arbitrary jury selection, the Gideon solution should be drawn upon, and a rule of law created to the effect that any arbitrary exclusion from, or inclusion in, the jury denies the defendant the impartial tribunal required by due process. ${ }^{28}$

24. 316 U.S. at 455, 462. But in Hamilton v. Alabama, 368 U.S. 52, 55 (1961), the Court asserted that "when one pleads to a capital charge without benefit of counsel, we do not stop to determine whether prejudice resulted."

25. Compare Gryger v. Burke, 334 U.S. 728 (1948), with Townsend v. Burke, 334 U.S. 736 (1948).

26. Cf. Hamilton ₹. Alabama, 368 U.S. 52, 55 ("The degree of prejudice an never be known.").

27. Cf. Ashcraft v. Tennessee, 322 U.S. 143, 154 (1944), and the notion of "inherently coercive" situations. As in Gideon, the presumption of injury was made irrebutable, and in effect this should be true also with respect to improper jury selection.

28. As the Supreme Court declared, and akin to the rule in Betts v. Brady, the defendant would have to prove this was a "special case." Fay v. New York, 332 U.S. 261, 293 (1947).

29. The effect of such a rule of law would be, in part, to make applicable to the slates the so-called "cross-section" standard of selection now applicable to the federal courts, which requires that juries be drawn from a cross-section of the population vithout arbitrary exclusions of economic, social, racial, or other groups. Thiel v. Southern $\mathrm{Pac}$. Co, 328 U.S. 217 (1946) ; Ballard v. United States, 329 U.S. 187 (1946); see also Glasser v. United States, 315 U.S. 60, 85-87 (1942). This standard is based upon the Supreme Court's assessment, in the exercise of its power of supervision over the administration of justice in the federal courts, of proper practice rather than upon due process rights of accused. $C$. McNabb v. United States, 318 U.S. 332, 340. Thus, "... it becomes unnecessary to determine whether the petitioner was in any way prejudiced by the wrongful exclusion or whether he was one of the excluded class." Thiel v. Southern Pac. Co., 328 U.S. 217, 225 (1946). As this Note has suggested, inherent in the due process right to an impartial tribunal is the notion that the broad representative character of the jury is an "assurance of a diffused impartiality." Thiel v. Southern Pac. Co., 328 U.S. 217, 227 (1946) (dissenting opinion). Four dissenting Justices (Black, Murphy, Douglas, and Rutledge) thought the defendant had such a right in Fay v. New York, 322 U.S. 261, 300 (1947):

We can never measure accurately the prejudice that results from the exclusion of certain types of qualified people from a jury panel. Such prejudice is so subtle, so intangible, that it escapes the ordinary methods of proof. It may ... erode the jury 
It might be argued that a defendant would not be affected if the state did not select a particular jury solely with reference to him. Thus, there wottd be no harm in a state attempting to ensure Negro representation throughout the jury system by intentionally selecting a fixed number of whites and Negroes for the general venire from which juries would then be drawn at random. The difficulty with this argument is that jurors who have been selected according to race either to sit on a particular jury or to be placed on a general venire

system before it becomes evident .... If the constitutional right to a jury impartially drawn from a cross-section of the community has been violated, we should vindieate that right even though the effect of the violation has not yet put in a tangible appearance.

See also Brown v. Allen, 344 U.S. 443, 474 (1953):

Our duty to protect the federal constitutional rights of all does not mean we must or should impose on states our conception of the proper sources of jury lists, so long as the source reasonably reflects a cross-section of the population suitable in character and intelligence for that civic duty. [Emphasis added.]

There is some indication that the pronouncement in Broven v. Allen will apply to the states as "something essential to fairness in trial by jury" but that in determining whether the procedures of selection were reasonably designed to obtain a cross-section, the fecleral courts would be held to higher standards than the states. United States $\varepsilon x \mathrm{rcl}$. Sturdivant v. New Jersey, 289 F.2d 846, 848 (3d Cir. 1961); Allen v. State, 110 Ga. App. 56, 137 S.E.2d 711 (1964). But see Rowland v. State, 213 Ark. 780, 213 S.W.2d 370 (1948) (refusal to extend cross-section rule). Accord, State v. Neff, 169 Kan. 116, 218 P.2d 248 (1950); State v. Taylor, 356 Mo. 1216, 205 S.W.2d 734 (1947). The question of what constitutes a method of jury selection which meets the "cross-section" test has caused some difficulty. See the discussion of the problem in United States v. Greenberg, 200 F. Supp. 382 (S.D.N.Y. 1961). See also Dow v. Carnegie-Illinois Steel Corp., 224 F.2d 414 (3d Cir. 1955), cert. denied, 350 U.S. 971 (1956); United States v. Dennis, 183 F.2d 201, 216-24 (2d Cir. 1950), aff'd, 341 U.S. 491 (1951).

The issue of whether a defendant in a state court has a constitutional right to a jury drawn from a cross-section of the community has tended to be confused by rhetoric concerning the dangers of imposing, on the one hand, "uniform procedures upon the several states" which would stifle "novel social and economic experiments" (Fay v. New York, supra at 296), and on the other hand, the dangers of making the jury "the representative of the most intelligent, the most wealthy or the most successful" which would fail to reflect "democratic principles" (Fay v. New York, supra at 299-300, dissenting opinion). Both the impartiality and competency of the jury are elements of due process. Obviously, in order to obtain competent jurors some persons must be excluded, and thus some classes must be under-represented (e.g., those without a 6 th grade education). The real issue is the relationship between the ends of impartiality and competency: does the system of eliminations reasonably further the end of securing a competent jury at the least possible cost of lessening the cross-section of persons who can be accepted for jury duty? In Fay v. New York, the "blue-ribbon" jury was selected to hear cases of wide publicity potential, and jurors were asked whether they would be influenced by newspaper reports, etc. the objection of the dissenters that professional workers had a greater representation on the panel was irrelevant so long as the qualifications were reasonable. Yet certain selection procedures would clearly be unreasonable. For example, a state law rcquiring jurors to have $\mathrm{Ph}$.D. degrees to judge murder cases might secure competent jurors, but it would eliminate too many other potential jurors who would also be competent, thus sacrificing the advantages of a larger cross-section. A requirement that jurors be white similarly eliminates too many jurors who would be competent, regardless of the competency of the jurors chosen. 
may well believe that they were picked because race is somehow relevant to the process of deliberation and that each race is expected to be partisan along racial lines. ${ }^{30}$ At the least, jurors who might be psychologically predisposed to be racially partisan would be given a subtle impetus. Thus even this type of racial selection should be viewed as a denial of an impartial tribunal.

But the argument that the use of racial criteria in the selection of a jury affects the reliability of the verdict may well be too speculative to support a finding of partiality and the accompanying due process right of reversal. A similar problem arises when the improper jury selection is confined to the grand jury level. For example, in Cassell $v$. Texas ${ }^{31}$ the exclusion of Negroes was confined to the grand jury, and the defendant subsequently received a fair trial. Despite this fact, the Supreme Court reversed the conviction. Justice Jackson, in dissent, pointed out that, unlike the situation of exclusion of Negroes from the petit jury, reversal for exclusion from a grand jury cannot be based upon a presumption of outcome-determinative injury. He argued that:

It hardly lies in the mouth of a defendant whom a fairly chosen trial jury has found guilty beyond reasonable doubt, to say that this indictment is attributable to prejudice... [I]t is frivolous to contend that any grand jury, however constituted, could have done its duty in any way other than to indict .... [T] his defendant has not been harmed. ${ }^{32}$

Although Justice Jackson failed to note that the Negro defendant may have been denied an impartial tribunal because of the exclusion of Negroes, he was nonetheless correct in asking how the remedy of reversal could be justified if the resulting indictment was not affected by the mode of grand jury selection. ${ }^{39}$ Indeed, the issue of the appropriate remedy must be faced in every case in which improper conduct has occurred in the selection of a jury, but outcome-determinative injury cannot be shown either because the conduct occurred only at the grand jury level or because a court is unwilling to accept an irrebutable presumption of prejudice.

Before discussing the propriety of reversing convictions in cases where the jury has been selected on racial grounds but no effect on reliability can be shown, it is first necessary to examine the alleged impropriety to determine whether any legal right has been invaded, and if so the nature of that right. Whenever a state uses racial criteria as a basis for government action in a context in which race seems irrelevant an equal protection issue arises. The appropriate

30. Cf. Anderson v. Mfartin, 375 U.S. 399, 402 (1964). There the Supreme Court invalidated the state practice of noting a candidate's race opposite his name on the ballot.

31. 339 U.S. 282 (1950).

32. Id. at $302,304$.

33. The Supreme Court however, as in Cassell, has continually reversed convictions on the ground of exclusions from the grand jury alone. See, e.g., Pierre v. Louisiana, 306 U.S. 354, 362 (1939) ("Principles which forbid discrimination in the selection of pstit juries also govern the selection of Grand Juries.") ; Eubanks v. Louisiana, 356 U.S. 584 (1958). For a discussion of Justice Jackson's view that there should be a distinction between improper grand jury and petit jury selection methods see Gibson, Racial Discrimistation on Grand Juries, 3 BAYLOR L. REv. 29 (1950). 
inquiry in Collins, therefore, was whether the method of selecting the grand jury violated the equal protection clause of the Constitution.

Judicial interpretation of the equal protection clause has resulted in the development of at least two quite different doctrines. ${ }^{34}$ One is the requirement that classifications be reasonably related to a valid legislative purpose, a requirement which has been used to invalidate some police power classifications; perhaps because of its enormous potential for judicial usurpation of the legislative function, this doctrine has been sparingly used. ${ }^{30}$ The equal protection clause, as so applied, is quite similar to the substantive application of the due process clause ${ }^{37}$ and requires two inquiries - the appropriateness of the classification and the validity of the purpose. ${ }^{38} \mathrm{~A}$ second doctrine under the equal protection clause has been developed primarily in the area of racial discrimination. In this area the Court has not been so hesitant to apply the clause, and a distinct set of criteria has been created. As Professor Bittker has pointed out, the "inescapable starting point" with respect to statutory classification by race is the Supreme Court's formulation in Hirabayashi v. United States:

Distinctions between citizens solely because of their ancestry are by their very nature odious to a free people whose institutions are founded upon the doctrine of equality. ${ }^{40}$

Race has been termed "constitutionally an irrelevance"41 and distinctions based on it "immediately suspect." ${ }^{\text {"42 }}$ Even racial classifications having a reasonable

34. With respect to the equal protection clause, see generally, Tussman \& tenBroels, The Equal Protection of the Laws, 37 CaIrs. L. Rev. 341 (1949).

35. E.g., Morey v. Doud, 354 U.S. 457 (1957); Smith v. Cahoon, 283 U.S. 553 (1931).

36. For instances in which the Court has refused to apply the equal protection clause, see McGowan v. Maryland, 366 U.S. 420 (1961); Salsburg v. Maryland, 346 U.S. 545 (1954); Williamson v. Lee Optical Co., 348 U.S. 483 (1955); Railway Express Agency v. New York, 336 U.S. 106 (1949); Goeseart v. Cleary, 335 U.S. 464 (1948). The most frequent application of the clause since 1880 has been to reverse the convictions of Negro defendants when Negroes were excluded from the jury. See, e.g., Strauder v. West Virginia, 100 U.S. 303 (1880); Norris v. Alabama, 294 U.S. 587 (1935); Eubanks v. Loutislanta, 356 U.S. 584 (1958). But the clause has found vitality also in the area of criminal procedure - see Griffin v. Illinois, 351 U.S. 12 (1956); Douglas v. California, 372 U.S. 353 (1963) - and with respect to malapportionment - see Baker v. Carr, 369 U.S. 186 (1962) ; Reynolds v. Sims, 377 U.S. 533 (1964).

37. Lindsley v. Natural Carbonic Gas Co., 220 U.S. 61, 78 (1911) ("if any state of facts reasonably can be conceived that would sustain [the classification], the existence of that state of facts ... must be assumed") ; Metropolitan Cas. Ins. Co. v. Brownel, 294 U.S. 580, 583 (1935). On the different consequences between using due process or cqual protection to invalidate legislation, see Railway Express Agency v. New York, 336 U.S. 106, 111 (1949) (Jackson, J., concurring); Bicket, The Least Dangerous Brancur 221-28 (1962).

38. See Tussman \& tenBroek, supra note 34 for the distinction between these two inquiries.

39. Bittker, The Case of the Checker-Board Ordinance: An Expcriment in Race Relations, 71 YaLE L.J. 1387, 1409 (1962).

40. 320 U.S. 81, 100 (1943).

41. Edwards v. California, 314 U.S. 160, 185 (1941) (Jackson, J., concurring).

42. Korematsu v. United States, 323 U.S. 214, 216 (1944). The ordinary presumption of constitutionality would not seem to apply in cases of governmentally imposed racial dis- 
relation to a valid legislative purpose have been struck down because the Court found the purpose also was discriminatory or disadvantaged a minority group. ${ }^{33}$ This rigid scrutiny of racial classifications reflects the fact that "the apprehended existence of prejudice" was a crucial reason for the adoption of the equal protection clause.44 Thus, it is not surprising that the Court has wielded the equal protection clause primarily to strike down legislation in contexts of obvious racial hostility and injury to minority groups.

This concept of injury or hostility may be sufficient to dispose of the more usual jury selection case where Negroes are excluded from a jury either because the defendant is Negro or because of a general state policy of exclusion. In the former situation the defendant would be denied equal protection, and in both cases the excluded Negro jurors would suffer a denial. But a showing of injury is more difficult in the Collins type of situation, posing as it does the question of whether an inclusion of Negroes in order to assure fairness is a denial of equal protection either to the defendant or to the jurors. ${ }^{45}$ Similarly, assume the case of a white defendant where Negroes were excluded because he was white. Although the Negroes may have been deprived of their constitutional right, may the defendant argue that he has been denied equal protection merely because he has been the subject of a racial classification?

Decisions since Brozen v. Board of Education ${ }^{\text {46 }}$ suggest that absent any strong demonstrable state need for racial classifications, the essence of the constitutional infirmity is the racial classification per se, regardless of concrete injury. Recent cases prohibiting the practice of designating the race of candidates for election opposite their names on the ballot ${ }^{\mathbf{2 7}}$ and striking down statutes requiring that public records be kept on a segregated basis ${ }^{48}$ indicate that

tinctions. Cf. United States v. Carolene Prods. Co., 304 U.S. 144, 152-53 n.4 (1938) ; Pollak, Racial Discrinination and Judicial Integrily: A Reply' to Professor Wechsler, 103 U. PA. L. REv. 1, 27 (1959).

43. Buchanan v. Warley 245 U.S. 60, 81-82 (1917) (against argument that racial zoning law was designed to preserve order by preventing racial conflict, and designed also to protect property values); Takahashi v. Fish \& Game Comm'n, 334 U.S. 410 (1948) (law designed as a fish conservation measure).

44. Strauder v. West Virginia, 100 U.S. 303, 309 (1880). See generally tzrnBrozs, The Anti-Slavery Origins of the Fourteentr Aasendaient (1951).

45. A vigorous dissent in the Collins case questioned how the intentional inclusion of Negroes on a grand jury could discriminate against a Negro accused: "if anything could be made clearer this defendant was benefitted by the intentional inclusion of Negroes, not discriminated against" 335 F.2d 417, 425 (1964) (Dawkins, J., dissenting).

Shortly after Collins, the United States Court of Afilitary Appeals flatly rejected the opinion of the Fifth Circuit and apparently approved the deliberate inclusion of a Negro on a Court-Martial to hear a case in which the accused was a Negro:

If deliberately to include qualified persons is discrimination, it is discrimination in favor of, not against, an accused. Equal protection of the laws is not denied, but assured.

United States v. Crawford, 15 U.S.C.M.A. 31, 41 (No. 3 Advance Opinions, Oct 5, 1964).

46. 347 U.S. 483 (1954).

47. Anderson v. Martin, 375 U.S. 399 (1964).

48. Hamm v. Virginia State Bd. of Elections, 230 F. Supp. 156 (E.D. Va. 1964), aff'd per curiam, 379 U.S. 19 (1964). See note 50 infra. 
"it is the stamp of classification by race that makes the classification invidiouts." These cases imply increasing recognition by the courts that the equal protection clause does not operate to prohibit racial classifications only when some specific injury to a minority group can be shown. ${ }^{50}$ Although the equal protection clause was adopted at a time when concrete and substantial injuries suffered by the newly-freed Negroes were in the forefront of men's minds, ${ }^{, 51}$ it is now - some one hundred years later - becoming clear that the fundamental evil against which the clause is being aimed is the premise that a race is a significant enough difference between persons to determine the way they should be treated. ${ }^{52}$ Contemporary application of the clause should be to proscribe the definitive element of a caste society: official emphasis upon race ${ }^{\text {t3 }}$ and en-

49. Anderson v. Martin, 206 F. Supp. 700, 705 (D. La. 1962) (dissenting opinion), rev'd, 375 U.S. 399 (1964).

The per ctriam decisions upsetting segregation in places of public accommodation did not discuss the consequences for the minority group. See, e.g., City Park Improvement Ass'n v. Detiege, 252 F.2d 122 (5th Cir.), aff'd per curriam, 358 U.S. 54 (1958); Holmes v. City of Atlanta, 223 F.2d 93 (5th Cir.), rev'd per curriam, 350 U.S. 879 (1955); Muir v. Louisville Park Theatrical Ass'n, 202 F.2d 275 (6th Cir. 1953), rev'd per curiam, 347 U.S. 971 (1954). These cases are thus consistent with the view that racial classifications are per se unconstitutional regardless of injury, but it seems obvious that implicit in such segregation was very real injury to the minority group. Some commentators have not had any difficulty in finding a rationale for the decisions, whereas others have been hardpressed. Compare Black, The Lazefulness of the Segregation Decisions, $69 \mathrm{Y}_{\text {ALE L L.J. } 421}$ (1960), with Wechsler, Toward Neutral Principles of Constitutional Law, 73 Hawv. L. REv. 1, 22 (1959).

50. The traditional view has been that racial classifications deny equal protection because they put a stamp of inferiority on a minority group. See Pollak, Racial Discrimination and Indicial Integrity: A Reply to Professor Wechsler, 108 U. PA. L. REv. 1, 28 (1959) ("[I]t is the function of Jim Crow laws to make identification as a Negro a matter of stigma."); Black, The Lauefulness of the Segregation Decisions, 69 YAlE L.J. 421 (1960). Calling a white person a Negro is, after all, defamatory in some jurisdictions. Natchez Times Publishing Co. v. Dunigan, 221 Miss. 320, 72 So. $2 d 681$ (1954). See also Hamilton v. Alabama, 376 U.S. 650 (1964), reversing, 275 Ala. 574, 156 So. 2 d 926 (1963) (Negro has a right to be properly addressed by his full name). But the more recent cases seem to go beyond resting the decision on that basis. In Hamm v. Va. State Bd. of Elections, 230 F. Supp. 156 (E.D. Va. 1964), aff'd per curriam, 379 U.S. 19 (1964), whitc plaintiffs had standing to attack the keeping of records on a segregated basis which would be questionable if it were held that racial classifications deny equal protection only because they put a stamp of inferiority on a minority group.

51. Note 44 supra.

52. The assertion of human equality is closely associated with the denial that differences in color or creed, birth or status, are significant or relevant to the way men should be treated. These factors, the egalitarian asserts, are irrelevant accidents in the face of our common humanity. To these differences in the supplicants before her bar, Justice must be blind. Laws which classify men by color or creed or blood accordingly, are repugnant to the demand for equality, and therefore, stuch traits should not be made the basis for the classification of individuals in laws.

Tussman \& tenBroek, The Equal Protection of the Laws, 37 Calur. L. Rev. 341, 353 (1949).

53. See Dollard, Caste and Crass in a Southern Town (3d ed. 1957); Isancs, INDIA's EX-UNTOUCHABLES (1965). 
couragement of the idea that it is a relevant factor in dealing with people. Since the state must be officially indifferent to a person's race, any classification or treatment of that person on the ground of his race, whether or not actual injury can be shown, is a denial to him of the equal protection of the law.

This view of the equal protection clause is analogous to the establishment clause as interpreted in Engel $v$. Vitale ${ }^{65}$ in that a substantive violation of equal protection does not depend upon injury to a person, but rather upon whether the state has engaged in a particular type of conduct. In Engel the State of New York adopted a program of classroom prayers in public school; no coercion of the children was found. In finding an establishment of religion, Justice Black stated that:

The Establishment Clause, unlike the Free Exercise Clause, does not depend upon any showing of direct governmental compulsion and is violated by the enactment of laws which establish an official religion whether those laws operate directly to coerce nonobserving individuals or not. ${ }^{5 B}$

The standard of unconstitutionality is addressed solely to the type of enactment without regard to injury; if the enactment fosters a "union of government and religion"57 it is unconstitutional. ${ }^{68}$ Of course, the establishment clause rests, inter alia, "upon an awareness of the historical fact that governmentally established religions and religious persecutions go hand in hand."Io But in the same way the equal protection clause rests upon an awareness of the consequences in a society which emphasizes racial differences. ${ }^{\circ 0}$ Any action which tends to break down the "wall of separation between Church and State," or which treats persons with regard to their race without an overriding state need for such classifications, is the "first experiment on our liberties" ${ }^{\text {"1 } 1}$ at which we should take alarm. ${ }^{62}$

54. The stress is on irrelevant racial distinctions. The suggestion is not that all racial classifications are per se unconstitutional regardless of injury, but only those classifications for which the state cannot show a strong demonstrable need, and which cannot pass scrutiny for possible discriminatory motive or long-run harmful effect. See notes 63-66 infra and accompanying text.

55. 370 U.S. 421 (1962).

56. Id. at 430 .

57. Id. at 431 .

58. See also the test announced in School Dist. v. Schempp, 374 U.S. 203, 222 (1963) ("a secular legislative purpose and a primary effect that neither advances nor inhibits religion").

59. 370 U.S. at 432 .

60. See notes 44 and 53 supra.

61. 370 U.S. at 436, quoting Memorial and Remonstrance against Religious Assessments, 2 WRITINGS of MLADISON 185-86.

62. The standing requirement has caused considerable difficulty with respect to plaintiffs challenging an establishment of religion because the establishment clause by its nature can be violated without injuring or materially affecting particular persons. Sec discussion in Brown, Quis Custodiet Ipsos Custodes? - The School Prayer Cases, 1963 Supneare 
A reply to the above argument might be that it fails to consider the benign purpose in Collins of securing Negro representation on the grand jury. However, Professor Bittker has marshalled a compelling argument against the constitutional validity of benign quotas in housing, ${ }^{03}$ and the reasons against them seem even stronger in the context of a criminal trial. Racial classifications can almost inevitably satisfy the "reasonable relation" and "valid purpose" tests. But the equal protection clause demands more than this where race is involved. At the very least, a strong social need, an absence of discriminatory motive, and a lack of harmful effect over the long-run must be demonstrated. ${ }^{44}$ These barriers would be virtually impossible to surmount with respect to jury selection. The Supreme Court has consistently disapproved of the idea that proportional representations of races on juries is a right of a defendant because necessary for a fair trial. ${ }^{65}$ The susceptibility to abuse of purportedly benign racial classifications is particularly great in the process of jury selection, which has been consistently infested with attempts at subtle discrimination. ${ }^{10}$ It seems clear that there can be no demonstrable state need for racial selection, since the state has available means for ensuring selection of a cross-section of the community on its juries which do not utilize the criteria of race.

Having established that any method of jury selection which is based on racial classification is a denial of equal protection either to the defendant or to the classified members of the jury, the inquiry can be refocused on the issue of proper remedy. Two basic approaches to the issue are possible. The first, and more traditional analysis, concentrates on the defendant's standing to raise the constitutional rights of third parties, and on deterrence as the basic rationale in constructing a remedy; the second approach would employ

Cr. Rev. 1; Jaffe, Standing to Secure Judicial Review: Public Actions, 74 Hanv, L. REv. 1265, 1309-12 (1961); Sutherland, Establishment According to Engel, 76 Harv. L. REv. 25 (1962).

The equal protection clause protects, like the due process clause, a "personal right" ; in contrast to the establishment clause, the standing issue and the substantive isste on the merits are the same. Cf. Lewis, Constitutional Rights and the Misuse of "Standing", 14 StaN. L. REv. 433 (1962). This Note has argued, simply, with respect to the issue on the merits that when the state classifies someone according to his race he has been denied equal protection; and that the classification is of such a nature that the "injury" is inherent in the classification quite apart from the more usual "injury" one associates with racial discrimination.

63. Bittker, The Case of the Checker-Board Ordinance: An Experiment in Race Relations, 71 YALE L.J. 1387 (1962).

64. See Pollak, supra note 50, at 26. Cf. Balaban v. Rubin, 14 N.Y.2d 193, 199 N.E.2d 375 , cert. denied, 379 U.S. 881 (1964) (sustaining school zoning plan to obtain racial balance).

65. Cassell v. Texas, 339 U.S. 282, 286-87 (1950); Akins v. Texas, 325 U.S. 398, 403 (1945) ; Virginia v. Rives, 100 U.S. 313, 322-23 (1880). In a case in which the ground for reversal was admittedly arguable, the Supreme Court may have implicitly held proportional representation unconstitutional. Shepherd v. Florida, 341 U.S. 50 (1951), reversing per curiam, 46 So. $2 d 880$ (1950).

66. See, e.g., Avery v. Georgia, 345 U.S. 559 (1953); see also 1961 Uniten STATEs Comirrssion on Civil Rights Report (Book 5), 93-94, 99 (1961). 
a due process analysis in order to construct a more general theory concerning the rights of criminal defendants. Although both approaches may, in the course of analysis, ask many of the same questions, the focus, breadth, and attitudes of each will be quite different.

The traditional analysis begins with an investigation of the defendant's standing to raise the substantive violation of the equal protection clause. If the jury has been selected with reference to the defendant's race, as in Collins, standing is clearly present since the defendant, as well as the jurors, has been denied equal protection; ${ }^{67}$ in this case the significant problem is that of redressing the constitutional deprivation. But if the defendant can assert only that the selection was made without reference to his own race but with regard to the jurors' race, the denial of substantive equal protection operates on the jurors, not the defendant. The situation which most clearly presents the problem of the defendant's standing to raise the constitutional rights of the jurors is that of a white defendant who challenges the exclusion or inclusion of Negro jurors and claims that this unconstitutional conduct should lead to reversal of his conviction. The white defendant will be unable to show that the action he is assailing as unconstitutional affected or injured him. To be sure, the defendant does possess what has been called "pure standing," as does any defendant who argues that reversal of his conviction is the remedy for the unconstitutional state action. Unless the defendant succeeds in his argument he will be imprisoned or will suffer those other consequences which stem from his conviction. ${ }^{69}$ But a finding of pure standing satisfies only the minimum constitutional requisite of a "case." In addition, the Supreme Court has fashioned other more rigorous but discretionary requirements which a defendant must meet before he can invoke the federal judicial power. Among these discretionary or "impure" standing concepts is that of " $j u s$ tertii" standing - the ability of a party to raise the constitutional rights of others. Although the Supreme Court has often denied such standing, the Court has just as frequently granted $j u s$ tertii standing. ${ }^{70}$ Since the doctrine is flexible and the grant of standing discretionary, the considerations underlying the rule must be examined in order to determine whether a defendant should be allowed to raise the constitutional rights of the jurors. ${ }^{71}$ Indeed, jury se-

67. See note 62 supra.

68. See generally Bickes, The Least Dangerous Branch 119-25 (1962).

69. Cf. Barrows v. Jackson, 346 U.S. 249 (1953).

70. See generally Sedler, Standing to Assert Constitutional Jus Teriii in the Supreme Court, 71 Y ALE L.J. 599 (1962).

71. A court, depending on its attitude toward the role of the courts and the exercise of their judicial power, could view the question of $j u s$ terlii standing in several ways. (1) The standing requirement in general serves little purpose, and may be necessary only to insure the presence of a "case"; the requirement in many instances results only in the avoidance of adjudication of cases that should be decided. Cf. School Dist. v. Schempp, 374 U.S. 203, 266 n.30 (1963) (Brennan, J., concurring); Doremus v. Board of Educ., 342 U.S. 429, 435 (1952) (Douglas, J., dissenting); Jaffe, supra note 62. (2) There is a pre- 
lection cases demand particularly careful scrutiny of the jus tertii claim because of the heavy price the defendant is asking society to pay for the vindication of another's constitutional rights - the reversal of a presumably reliable conviction.

An initial inquiry in the jus tertii analysis requires a determination of the importance of the third party's rights, which the defendant is attempting to assert. In the case of improper jury selection, it is sufficient to say that although any attempt to place constitutional rights within a hierarchical framework is a most difficult if not peculiar task, the right of equal protection and the security from the evils of race discrimination it affords is a most significant one, and at the present time, a right to which our political and judicial institutions have given ever increasing protection.

A second consideration in evaluating the propriety of granting jus tertii standing is whether existing remedies are sufficient to protect the constitt1tional right. It seems obvious, however, that the three existing remedies are insufficient, since there is every indication that widespread unconstitutional exclusion of Negroes from juries is prevalent. ${ }^{72}$ An injunctive suit might be brought by the excluded juror under Section 1983 of Title 42 of the United States Code. ${ }^{73}$ But only one suit for an injunction has ever been brought under Section 1983, ${ }^{74}$ presumably because of the lack of initiative on the part of private citizens to undertake such costly litigation. Federal prosecution of election officials is available under Section 243 of Title $18 .^{75}$ Yet only one

sumption against hearing such cases unless certain conditions are met. The policies under* lying the standing requirement are so important, and the abstention from the excrcise of judicial power thus the norm, that any deviation from traditional restraint requires compelling reasons. Cf. Poe v. Ullman, 367 U.S. 497 (1961). (3) Jus tertii standing is discretionary, and a grant of such standing is a matter of balancing the various policies underlying the standing requirement. Cf. NAACP v. Alabama ex rel. Patterson, 357 U.S. 449 (1958); Barrows v. Jackson, 346 U.S. 249 (1953). This third approach is the perspective from which this Note will analyze challenges to jury selection.

72. See 1961 United States Commission on Civil Rigris Report (Book 5), 89-92.

73. Rev. Stat. § 1979 (1875), 42 U.S.C. $\$ 1983$ (1958) :

Every person who, under color of any statute, ordinance, regulation, custom, or usage of any State or Territory, subjects, or causes to be subjected, any citizen of the United States or other person within the jurisdiction thereof to the deprivation of any rights, privileges, or immunities secured by the Constitution and laws, shall be liable to the party injured in an action at law, suit in equity, or other proper proceeding for redress.

74. Brown v. Rutter, 139 F. Supp. 679 (W.D. Ky. 1956) (holding that Negro plaintiff was entitled to an injunction on proof of exclusion of Negroes from juries but injunction was deferred since jury officials said they intended to cease discrimination).

75. 18 Stat. 336-37 (1875), 18 U.S.C. $\$ 243$ (1958) :

No citizen possessing all other qualifications which are or may be prescribed by law shall be disqualified for service as grand or petit juror in any court of the United States, or of any State on account of race, color, or previous condition of servitude; and whoever, being an officer or other person charged with any duty in the selcction or summoning of jurors, excludes or fails to summon any citizen for such cause, shall be fined not more than $\$ 5,000$. 
prosecution has been brought under this section (in 1878), ${ }^{70}$ primarily because it would be difficult to obtain convictions in localities where racial discrimination is common, and because the Justice Department has not been able to secure information from United States Attorneys concerning jury exclusion. ${ }^{7 T}$ The third remedy for improper selection procedures is challenge by defendants asserting their own constitutional rights. An obvious reason why this remedy has not been effective is that not enough objections have been forthcoming, no doubt because of the rule that only Negroes can object to the exclusion of Negroes from juries.

Since the concept of impure standing is designed, in part, to insure that only concrete cases be heard, another factor of importance is whether the party asserting the rights of others is capable of presenting and fully developing all the relevant issues. ${ }^{78}$ In some ways this may be an absolute requirement; if the facts of the case are not presented in sufficient detail, decision on the merits will be impossible. But more commonly, the issue of concreteness is comparative: would the party whose rights were actually denied be able to present a more fully developed record? Insofar as incentive to develop the issues is concerned, the defendant - raising the issue to avoid a conviction seems to have "such a personal stake in the outcome of the controversy as to assure that concrete adverseness which sharpens the presentation of issues." But it might be true that, at least in some cases, the defendant is not in as good a position as the excluded or included juror to develop the facts necessary to prove the alleged improper jury selection procedure. Discrimination in jury selection is often of such subtlety that only the juror will have knowledge of the facts. In many cases, however, proof of exclusion does not involve facts which only the excluded juror could develop, but rather involves a statistical investigation which the defendant can conduct as well as anyone else. ${ }^{80}$ Moreover, this consideration - that a particular person is best able to develop certain issues - may be overemphasized. The defendant and his lawyer, employing available investigatory resources, direct testimony by witnesses, and modern discovery procedures should be able sufficiently to present the necessary facts. If the defendant fails to prove discrimination, it is more likely that the proof failed for reasons other than that the defendant was not as immediately affected as was the excluded juror.

76. Ex parte Virginia, 100 U.S. 339 (1880), upholding the constitutionality of $\$ 243$ in denying a petition for habeas corpus by a judge indicted and imprisoned for jury discrimination. The original case is unreported, except for the charge to the federal grand jury which indicted the judge. See Charge to Grand Jury - Civil Rights Act, 30 Fed. Cas. 1002 (No. 18259) (C.C.W.D. Va. 1878).

77. Op. cit. supra note 72, at 102.

78. BICKEI, op. cit. supra note 68 , at 123.

79. Baker v. Carr, 369 U.S. 186, 204 (1962).

80. See, e.g., Reece v. Georgia, 350 U.S. 85 (1955) ; Norris v. Alabama, 294 U.S. 587 (1935); United States ex rel. Seals v. Wiman, 304 F.2d 53 (5th Cir. 1962), cert. deried, 372 U.S. 924 (1963). 
Another relevant but difficult consideration which may bear upon the grant of jus tertii standing is whether the relationship between the courts and representative political institutions should preclude the exercise of judicial power in such cases. ${ }^{81}$ The standing requirement is preeminently a doctrine which restricts the exercise of judicial power. ${ }^{82}$ Since the Court is ultimately a political institution, its survival may depend upon its success in avoiding friction with other political institutions. But many of the factors which ustually suggest that the Court abstain from the exercise of power because of the danger of a "political clash" do not militate toward abstention in the jury cases. First, the requirement of standing promotes a time lag between the passage of legislation, when support for it is strongest, and the Court's review at a later time, when experience and time have tempered initial judgment. ${ }^{88}$ This policy does not seem germane to jury cases involving discriminatory practices which have been going on for years. Indeed, popular support for these practices is probably waning, as evidenced by reforms over the last decade in civil rights. Discriminatory selection practices often are not sanctioned by state statutes but involve administrative practices by local and often minor, political officials. The clash, if any, will not be between courts and state legislatures but between courts and local jury commissioners. ${ }^{84}$ Since increasing numbers of Negroes are obtaining the franchise in the South, it can also be said that the possibility of conflict between a court and Southern political institutions is slowly fading, as the base of political power shifts toward the Negro. It is further argued that a court best avoids clashes with political institutions by acting only when it has something unique and non-political to offer - that is, a perspective different from that of a legislature, derived from adjudication of concrete cases where the impact of legislation can be seen. ${ }^{85}$ But this limit on the exercise of a court's power presents little problem in the jury cases, which involve the actual fact of discriminatory practices; the defendant is not attacking an abstract problem before it has affected particular persons. ${ }^{86}$

Regardless of the considerations which may point toward recognition of jus tertii standing, such standing cannot be granted unless reversal of the conviction is found to be both an appropriate remedy and an effective deterrant to unconstitutional methods of jury selection. Indeed, whether or not the

81. Of all the considerations underlying standing, this one depends most heavily on the court's attitude toward the judicial process. See note 71 supra.

82. See Ashwander v. Tennessee Valley Auth., 297 U.S. 288, 346-48 (Brandels, J., concurring); Bickel, Foreward: The Passive Virtues, 75 Harv, L .REv. 40 (1961).

83. BICKEL, op. cit. supra note 68 , at 116.

84. Moreover, any conflict would not concern all fifty states but primarily those few in the South; and, of course, there is no difficulty here concerning the relationship between the courts and Congress.

85. BICKEI, op. cit. sitpra note 68 , at 115-16.

86. Finally, it might be noted that there is of course no question concerning the justiciability of the issue. Compare Colegrove v. Green, 328 U.S. 549 (1946), with Gomillion v. Lightfoot, 364 U.S. 339 (1960). 
defendant has pure standing hinges on whether reversal of the conviction is the remedy which will in fact be granted. Unless the remedy of reversal as opposed, for example, to money damages to the jurors - vould follow from the assertion by the defendant of the constitutional rights of the jurors, the outcome of the litigation will have no consequences at all for the defendant. If reversal is not an effective deterrant, however, there is no justification for the grant of that remedy and for jus tertii standing. Otherwise, the result would be to allow a certain number of reliably convicted defendants to go free without providing an effective remedy for the juror's deprivation.

There may be doubt whether a grant of standing to defendants in order to raise the juror's rights would be effective. The efficacy of the remedy of reversal rests upon the assumption that the state would be forced to retry those convicted persons who challenged the jury irregularity and that to do so it would have to eliminate improper selection procedures. This assumption, in turn, presupposes that challenges would be forthcoming from a significant number of defendants. If this were not the case, the state could simply not retry those few who challenged the selection procedures. Only if enough defendants challenged selection methods would the alternative of not retrying such defendants be foreclosed because of the threat to public safety from letting so many guilty persons go free. It is, however, possible that not enough challenges would be forthcoming. There are several reasons why Negroes have been deterred from challenging jury selection, and these reasons might also dissuade white defendants were they given standing. First, the defendant has the burden of proof, and in order to make out a prima facie case of discriminatory exclusion must commonly prove: that Negroes constituted a substantial segment of the population of the jurisdiction; that some Negroes. were qualified to serve as jurors; and that none or relatively few had been called_for jury service over an extended period of time. ${ }^{67}$ Gathering this proof can be time-consuming and expensive, and thus particularly onerous for court-appointed defense attorneys. ${ }^{83}$ As methods of discrimination become more sophisticated, the problems of proof can be expected to become more difficult. Also, Southern attorneys are very reluctant to challenge discriminatory selection, a fact notorious enough to have been the subject of judicial notice by the Fifth Circuit. ${ }^{80}$ Finally, inasmuch as objection to the jury usually must be timely (prior to trial) a defendant would gain little

87. These elements constitute prima facie proof of systematic exclusion under the socalled "rule of exclusion" set forth in Norris v. Alabama, 294 U.S. 587 (1935). Sec also Hernandez v. Texas, 347 U.S. 475 (1954); United States ex rel. Seals v. WViman, 263 F.2d 71 (5th Cir. 1962), cert. denied, 372 U.S. 924 (1963).

88. See United States ex rel. Seals v. Wiman, supra note 87.

89. As Judges of a Circuit comprising six states of the deep South, we think that it is our duty to take judicial notice that lawyers residing in many southern jurisdictions rarely, almost to the point of never, raise the issue of systematic exclusion of Negroes from juries. ...

United States es rel. Goldsby v. Harpole, 263 F.2d 71, 82 (5th Cir.), corl. denied, 361 U.S. 850 (1959) ; see Note, 72 YALE L.J. 559 (1963). 
by challenging the selection procedures. These impediments to the assertion of improper jury selection, however, seem to be diminishing. There is some indication that federal courts are permitting post-conviction habeas corpus review in cases where timely objection to jury selection was not made.00 This willingness to allow collateral attack has been based, in part, on the notion that utilization of broad pretrial discovery under the Federal Rules will present the defendant with his first realistic opportunity to prove discriminatory selection, and, in part, on findings that the defendant did not actually waive his right to object because his attorney was reluctant to raise the issue. Under this permissive doctrine of habeas corpus, more objections should be forthcoming.

Even if it is assumed that reversal of convictions will deter the use of unconstitutional selection procedures and thus redress the denial of equal protection to jurors, the issue of the propriety of this remedy must be resolved. A problem that is always present when deterrence is thought to justify a particular remedy is that of setting some limit to the deterrence rationale. It may well be true that reversing convictions would be an effective way to deter improper jury selection. But reversing convictions may also be an effective way to deter other kinds of improper state action. For example, convictions of all felons could be reversed until the state ceased to deny Negroes the right to vote. Mapp v. Oltio, ${ }^{, 1}$ however, indicates that deterrence of unconstitutional conduct through reversal of convictions is a proper remedy, despite the inherent difficulties of limiting the breadth of the doctrine. Although the defendant in Mapp, not a third party, suffered the unconstitutional deprivation, the importance of the constitutional right at stake in the jury selection cases and the grant of analogous remedies in similar $j u s$ tertii cases ${ }^{02}$ suggest that reversil of the conviction is an appropriate remedy. A further and decisive factor, which should resolve all doubts concerning the propriety of the remedy and concerning the desireability of granting jus tertii standing, is that no remedy other than reversal has been suggested or employed to eliminate the violation of the jurors' constitutional rights to equal protection of the law; absent the grant of standing to the defendant and the remedy of reversal of conviction, these rights apparently cannot be vindicated.

The second approach to the problem of unconstitutional jury selection procedures focuses on the scope of the defendant's due process right to indictment and trial by properly selected juries. In analyzing the content of the fourteenth amendment it is essential to distinguish the two kinds of values which the Supreme Court has recognized as inherent in the notion of due

90. See United States ex rel. Seals v. Wiman, 263 F.2d 68-69; Goldsby v. Harpole, supra note 89, at 83-84; Whitus v. Balkcom, 333 F.2d 496 (5th Cir.), cert. devied, 85 Sup. Ct. 329 (1965).

91. 367 U.S. 643 (1961).

92. Cf. NAACP v. Alabama ex rel. Patterson, 357 U.S. 449 (1958) ; Barrows v. Jackson, 346 U.S. 249 (1953). 
process. $^{93}$ Some procedural rights are obviously designed to protect the important value of "insuring the reliability of the guilt-determining process," reducing to a minimum the possibility that any innocent individual will be punished. The right to counsel ${ }^{94}$ and the right to be tried by an impartial tribunal ${ }^{95}$ are examples. But other procedural rights, which the Court has found within the meaning of due process, rest upon values other than the prevention of outcome-determinative injury. Among the values sought to be protected are a respect for the dignity of the individual, a desire to maintain the integrity of the criminal process, and an abhorrence of the misuse of official power in the administration of criminal justice. For example, the rule against the admission of coerced confessions cannot be explained solely upor the ground that they are untrustworthy. ${ }^{90}$ The broader basis for the exclusionary rule, as developed in Rogers $v$. Richmond, ${ }^{07}$ is the policy, fundamental to the accusatorial system and the privilege against self-incrimination, that the accused should not be made an involuntary author of his own conviction. ${ }^{03}$ Similarly, Mapp v. Ohio may be explained, at least in part, as resting on this concept of due process. ${ }^{99}$ Illegally obtained evidence is excluded from trial not because of its lack of reliability, but because admission of such evidence would impair the integrity of the criminal process and would tacitly condone improper techniques of law enforcement by lending apparent judicial approval to the unconstitutional search and seizure. As these cases suggest, in some circumstances a defendant is entitled by procedural due process requirements to a criminal process the crucial stages of which are not tainted by unconstitutional or otherwise improper state behavior. This concept of procedural due process makes the observance of certain standards of conduct by the state a condition precedent to the conviction of a defendant, regardless of whether outcome-determinative injury can be shown. Application of this concept de-

93. See generally Allen, Due Process and State Criminal Procedure: Another Lool, 48 Nw. U.L. Rev. 16 (1953) ; Kadish, Methodology and Criteria in Due Process Adjndication - A Survey and Criticism, 66 YALE L.J. 319, 346-49 (1957); Paclier, Two Mrodels of the Criminal Process, 113 U. PA. L. REv. 1 (1964).

94. Gideon v. Wainwright, 372 U.S. 335 (1963).

95. Tumey v. Ohio, 273 U.S. 510 (1927); Mfoore v. Dempsey, 261 U.S. 86, 91 (1923).

96. Wigmore argues that the exclusion of coerced confessions should rest on the untrustworthy nature of such evidence. 3 Wigarore, Evidence $\$ \$ 822-26$ (3d ed. 1940).

97. 365 U.S. 534, 540-41 (1961). See also Spano v. New York, 360 U.S. 315 (1959); Watts v. Indiana, 338 U.S. 49, 54-55 (1949).

98. The coerced confession rule, the privilege against self-incrimination, and a distaste for unconscionable police methods are interrelated. See Allen, Due Process and Slole Criminal Procedure: Another Look, 48 Nw. U.L. Rev. 16, 18-22 (1953); MreCormick, Some Problems and Developments in the Admissibility of Confessions, 24 TExis L. REv. $239-45$ (1946); McCormick, The Scope of Privilege in the Law of Evidence, 16 Texus L. Rev. 447, 452-57 (1938); Morgan, The Privilege Against Self-Incrimination, 34 Mnns. L. Rev. 1, 27-30 (1949); 8 Wigmore, Evidence \& 2266 (McNaughten rev. 1961). Two recent cases, though focusing on the right to counsel, involve the same thrust as Rogers v. Richmond in implicitly securing to the accused the privilege against self-incrimination. Escobedo v. Illinois, 378 U.S. 478 (1964); Mrassiah v. United States, 377 U.S. 201 (1964). 99. 367 U.S. at 659 . 
pends upon three inquiries: what are the crucial stages of the criminal process at which improper behavior will constitute a denial of due process; what standards of conduct are required at each of these important stages of the criminal process; does it matter whether the unconstitutional or otherwise improper behavior is directed toward the defendant or toward a third party?

Identification of the stages of the criminal process which are comprehended by due process is admittedly difficult, and the Supreme Court cases may be read to establish inconsistent rules. For example, Mapp v. Ohio seemingly rested upon the proposition that searches and seizures are part of the criminal process; Frisbie v. Collins, ${ }^{100}$ on the other hand, explicitly denied that arrest is a stage of the process comprehended by due process. But consistency may be achieved if the due process rules excluding coerced confessions and illegally seized evidence are viewed as based upon the idea that although securing confessions and searching for evidence are stages of the process, they are tangential enough that convictions following constitutional violations at those stages need only be reversed if the fruits of the violation are later used at trial. But regardless of the intricacies of determining the reach of due process at the pre-arrest stage, no one has ever doubted that the grand jury, and a fortiori, the petit jury, are crucial stages of the criminal process. The fact that the criminal process can constitutionally be initiated by information ${ }^{101}$ does not mean that the grand jury is not an integral stage of the process at which che process standards must be observed.

Once it is established that grand and petit juries are important points within the criminal process, the next and most important inquiry is what standards of conduct at the jury stage are imposed upon the state by due process. Without attempting to catalog the standards of behavior that are required by due process, equal protection of the law should certainly number among them. The search for due process limitations on state behavior might well begin with existing constitutional prohibitions. Certainly when a proscription of state conduct is contained in the fourteenth amendment, as is the case with the equal protection clause, the importance of the standard is obvious, and it does not seem difficult to conclude that such unconstitutional behavior is inconsistent with the notion of ordered liberty. Furthermore, the equal protection clause, as applied to jury selection, promotes values that traditionally have been felt to be at the core of due process: the dignity of the individual defendant, the integrity of the criminal process, and the premises of a democratic society. To select a jury with regard to the race of the defendant or to the race of other jurors is to confirm publicly the basic tenet of a caste system - that race is a relevant criterion in dealing with people; and it is intrinsic to a caste society that it systematically deprives its lower orders of the attributes of human dignity. ${ }^{102}$ Moreover, to exclude jurors for

100. 342 U.S. 519, 522 (1952).

101. Hurtado v. California, 110 U.S. 516 (1884).

102. See note 53 supra. 
racial reasons demeans the criminal process as a source of law and justice; such conduct is not only lawless in its own right, but may lead to a lack of public confidence in the administration of criminal justice, at least among Negroes, and to an attitude of being above the law among whites. ${ }^{103}$ Finally, such racial selection conflicts with the central role of the jury in a democratic society. The long tradition of basing eligibility for jury service on eligibility to vote ${ }^{104}$ indicates the close connection which Anglo-American democracy has seen between political and legal participation. At the same time, it has always been deemed one of the most fundamental rights of a criminal defendant that he be judged only by his peers. Both of these beliefs support the principle - long recognized in the federal courts - that prospective jurors should be selected from the broadest possible base in the community. ${ }^{205}$ Thus, with respect to jury selection, it seems clear that equal protection and due process point to the same fundamental values and that it is particularly appropriate to include equal protection among the limitations imposed by the due process clause upon the kinds of criminal procedures that will support a conviction. ${ }^{106}$

103. Our government is the potent, the omnipresent teacher. For good or for ill, it teaches the whole people by its example .... If the government becomes a lawbreaker, it breeds contempt for law; it invites every man to become a law unto himself; it invites anarchy.

Olmstead v. United States, 277 U.S. 438, 485 (1928) (Brandeis, J., dissenting).

104. This is a common state requirement - e.g., CoNr. Gen. Star. ANr. tit. 51, § 51-217 (Supp. 1964); MIcr. Stat. ANN. § 27.824(5) (Supp. 1963) - but not a federal requirement. Prior to the Civil Rights Act of 1957 , persons incompetent to serve on juries according to state law were also incompetent to serve on federal juries. 62 Stat. 951 (1948). The 1957 Act set qualifications for federal jurors independent of state law. 71 Stat. 639 (1957), 28 U.S.C. $\$ 1861$ (1958). The purpose was to eliminate indirect racial diserimination in federal courts as, for example, in Mississippi where jurors must be voters but Negroes are not allowed to vote. See 103 CoNG. Rec. 13154 (1957) (remarks of Sen. Church).

105. See note 29 supra.

106. If the conviction is itself the substantive deprivation which constitutes the denial of equal protection there is no need to invole due process. For example, if a state could be proved to have a policy of convicting only Negroes for a particular offense, such convictions would themselves be the denial of equal protection and hence void. Nor is there need to invoke due process if the resulting conviction was caused by or was a product of the denial of equal protection. Cf. Johnson v. Virginia, 373 U.S. 61 (1963) (reversal of contempt conviction of a Negro for refusing to sit in "Negro section" of courtroom); Hamilton v. Alabama, 275 Ala. 574, 156 So. 2d 926 (1963), rev'd, 376 U.S. 650 (1964); Peterson v. City of Greenville, 373 U.S. 244 (1963). See also Strauder v. West Virginia, 100 U.S. 303, 309 (1880) ; Norris v. Alabama, 294 U.S. 587 (1935); Avery v. Georgia, 345 U.S. 559 (1953) (reversal of Negro defendants' conviction on equal protection grounds when Negroes excluded from petit jury). But in other cases such as Collins $v$. Walker in which the procedure involved was neither intended nor likely to cause a discriminatory outcome, the conviction itself would not deny equal protection. In such cases the connection between the substantive denial of equal protection and the conviction which followed is established through due process, which holds that selection of the grand and petit jury is a crucial stage of the criminal process at which stage due process standards - among them, 
A final issue arises when the jurors, but not the defendant, have been denied equal protection. Does this conduct, standing alone, violate the defendant's right to due process, requiring reversal of the conviction? It is clear that the unconstitutional state conduct took place at a crucial stage of the criminal process during which due process standards must be observed as a condition precedent to a conviction. In addition, whether the jury is selected with reference to the defendant's race or to the race of the jurors, the state by affirming the tenets of a caste society has failed to respect the dignity of the individual at an important stage of the process. The harm to the integrity of the criminal process is the same in either case. A fundamental basis for requiring the observance of certain standards as a condition precedent to a conviction is that because "power is always subject to abuse, sometimes subtle, other times, as in the criminal process, open and ugly," 107 the state itself is on trial whenever it invokes the criminal process. This open abuse of power by the state in the course of obtaining a conviction should be considered a failure to aftord the defendant due process, regardless of whom the unconstitutional state conduct may have affected in the first instance. ${ }^{108}$ Reversal of criminal convictions which have been tainted by such state action is required not so much as a deterrent to those who disregard fundamental values, but as "an affirmation of proper values." 109

The most obvious difference between the jus tertii and due process analyses is that in some cases application of the respective theories may produce different results. ${ }^{110}$ But this distinction, drawn on an empirical level, is just one reflection of more significant differences between the theories. Use of the jus tertii analysis does not facilitate generalization from one case to another; the analysis does not readily lead to creation of a single theory applicable to all criminal cases. A due process theory, on the other hand, offers a general framework of analysis which applies throughout the criminal system; its use may allow rationalization of seemingly diverse and unrelated precedents, including Mapp v. Ohio, Cassel v. Texas, ${ }^{111}$ and Rogers v. Richmond, by focusing on whether the state has observed certain conditions precedent to

equal protection - must be observed. Equal protection in the process is a condition precedent to a conviction, but it is due process which voids a conviction secured in the absence of all the applicable conditions precedent.

107. Packer, Two Models of the Criminal Process, 113 U. PA. L. REv. 1, 16 (1964).

108. The same analysis would hold that a defendant has a due process right to a reversal when evidence illegally seized from someone other than the defendant is introduced at his trial. At the present time, if the accused was not the victim of the illegal search or seizure he has no standing to suppress the evidence. Wong Sun v. United States, 371 U.S. 471, 491-92 (1963); Goldstein v. United States, 316 U.S. 114, 121 (1942) (dictum). He must ordinarily show a possessory interest in the property or presence at the time of the search. Jones v. United States, 362 U.S. 257 (1960). The same result has been advocated under a jus tertii analysis. See Sedler, supra note 70, at 656-58.

109. Packer, supra note 107 , at 55. See note 103 supra.

110. See note 112 infra.

111. See note 31 supra and accompanying text. 
a valid conviction. A more fundamental difference between the theories is their difference in emphasis. Jus tertii asks questions such as whether the record is concrete, whether adjudication will cause a clash between the court and other political institutions, and whether no other effective means exists to remedy the unconstitutional state conduct. Although notions of deterrence may not be wholly lacking in the due process theory, the most important issues are what stages of the criminal system are central to the process and what standards of conduct must be observed at each stage. ${ }^{112}$ Underlying all of these distinctions is, of course, a fundamental difference in attitude toward constitutional adjudication. The jus tertii analysis, as a part of the standing doctrine, is primarily concerned with the propriety and desirability of exercising the judicial power. Due process involves close judicial scrutiny of the procedures used by the state in administering criminal justice and seeks to maintain values perceived as integral to our society. This basic conflict may be capsulized by the trite and frequently pejoritive terms "judicial restraint" and "judicial activism." And ultimately it is this difference in the conception of the judicial process which will determine a court's choice between the jus tertii and the due process approach.

112. This conception of due process would be reflected in dealing with another problem in the search and seizure cases: if illegally seized evidence is introduced at a trial (whether or not seized from the defendant, see note 103 supra), should the conviction be reversed if there is enough other evidence to support the conviction? In other words, an the erroneous admission of evidence obtained by an illegal search and seizure be subject to the rules of "harmless error"? If all that were involved was a deterrence rationale one might be pragmatic and conclude that no deterrent function would be served, and that to reverse would only result in a "needless retrial." See Fahy v. Connecticut, 375 U.S. 85, 92 (1963) (dissenting opinion); People v. Parham, 384 P.2d 1001, 33 Cal. Rptr. 497 (1963); Note, 64 CorUns. L. REv. 367 (1964). But if what is at stake is that conditions precedent to a conviction have not been met, the conviction cannot stand. A conviction is an affirmation of the observance of due process values and cannot stand if they have not been observed; the retrial is more than "needless." 